\title{
Influence of deformation on electrochemical properties of Q235 steel
}

\section{Vliv deformace na elektrochemické vlastnosti oceli Q235}

\author{
Zheng M. ${ }^{1}$, Shuai $M .^{2}$, Yu ${ }^{3}{ }^{3}$ \\ ${ }^{1}$ School of Chemical Engineering, Northwest University, Xi'an, China \\ ${ }^{2}$ School of Physics, Northwest University, Xi'an, China \\ ${ }^{3}$ School of Life Sci. \& Tech., Northwest University, Xi'an, China \\ E-mail: mszheng2@yahoo.com
}

The influence of deformation on electrochemical properties of Q235 steel is studied. The uni-axial tension of the steel is conducted on universal testing machine to get a series of strain, $0.07 \%, 6 \%, 11 \%$ and $24 \%$, respectively. The deformation process for strain of $0.07 \%$ is controlled by load, and the others are controlled by displacement correspondingly. Afterward, the tests of potentiodynamic polarization and electrochemical impedance spectroscopy are conducted for the deformed steel in $0.01 \mathrm{~mol} . \mathrm{dm}^{-3}$ $\mathrm{NaCl}$ solution. The results showed that plastic deformation leads to crystalline grains refine and elongate, and crystalline boundary increases, it induces more corrosive possibility and lower corrosive resistance; the corrosion potential of Q235 steel becomes more negative with the increase of deformation amount, and the corrosion current density increases with the amount of deformation; the corrosion resistance decrease with the increase of deformation seriously.

\section{INTRODUCTION}

Plastic deformation is the common process of metal forming and processing. Machines in service could also suffer from plastic deformation due to excessive loads. Many properties will change when steels bearing plastic deformation. For steel, its corrosion resistance will be reduced after the material undergoing plastic deformation, besides the working hardening and reduction of ductility, etc [1-6]. It is extremely necessary to analyze the influence of deformation on corrosive behavior of material in detail, so as to get sufficient information for rational utilization and optimization of the production processing of materials.

Singh et al studied the environmental corrosion of cold rolled Austenitic stainless steel [1]. The investigation indicates that deformation induced martensite increases in cold rolling with 0 to $80 \%$ reduction of thickness of the samples and hardness increased from $208 \mathrm{HV}$ to $468 \mathrm{HV}$; simultaneously, atmospheric corrosion rate and the immersion test corrosion rate decrease with increasing reduction in thickness of the samples by cold rolled deformation. P. Jacques et al studied the deformation - corrosion interactions for $\mathrm{Zr}$ alloys during
V rámci práce byl studován vliv deformace na elektrochemické chováni oceli Q235. Na tesovacím zařizeni bylo aplikováno jednoosé napětí za účelem dosažení deformace 0,07\%, $6 \%, 11 \%$ a 24\%. Deformace na úrovni 0,07\% byla dopočitána z úrovně mechanického napětí, zatímco ostatní byly reálně měreny posunem přičníku. Poté byly vzorky měreny pomoci potenciodynamických křivek a impedančnich spekter v roztoku $0,01 \mathrm{~mol} . \mathrm{dm}^{-3} \mathrm{NaCl}$. Výsledky ukazuji, že plastická deformace vede ke zjemnění a protažení zrn, nárůstu plochy hranic zrn, což má za následek nižši korozni odolnost. Samovolný korozni potenciál se stává negativnějším s nárůstem deformace a korozni proudová hustota vzrůstá a polarizačni odpor klesá.

I-SCC crack initiation [2,3], it was concluded that no crack initiation could be detected following the tests in an inert atmosphere; The iodine induced stress corrosion initiation mechanism must therefore be considered as a corrosion-strain interaction; the major parameter controlling the nucleation of the intergranular cracks is not related to grain to grain strain incompatibilities, but to the orientation of the grain boundary planes with respect to the tensile stress.

Haanappel et al studied the corrosion properties of an AISI 304 (UNS S30400) stainless steel food-service utensil by linear polarization, Tafel plots, and cyclic polarization, performed in a sodium chloride $(\mathrm{NaCl}) /$ water solution at $20^{\circ} \mathrm{C}$ [4], they concluded that an increasing degree of deformation resulted in a decrease in the corrosion current density, whereas after cyclic polarization the number of pits increased. However, crevice corrosion was always observed after cyclic polarization measurements

Mazza et al studied the relationship between the electrochemical and corrosion behavior and the structure of stainless steels subjected to cold plastic deformation [5], their electrochemical measurements realized that the lowering effect on the hydrogen overvoltage is higher 
with the deformation degree of the stainless steels in cold working at the liquid nitrogen temperature; the influence of the room temperature cold plastic deformation is much more notable for the AISI $304 \mathrm{~L}$ than for the AISI $316 \mathrm{~L}$ steel; the change from sulfuric acid to hydrochloric acid solution magnifies the unfavorable effects of the degree of work hardening on the occurrence of the passivation phenomena and on the protective characteristics of the passivating films to an extent, which depends on the orientation of the specimen surface with respect to the deformation direction and on the deformed temperature; all types of cold plastic deformation cause the critical pitting potential of the stainless steels to diminish. Rifai et al studied the effect of ECAP deformation Route on microstructure, mechanical and electrochemical properties of low $\mathrm{CN} \mathrm{Fe}-20 \% \mathrm{Cr}$ Alloy [6], it revealed that the mechanical properties by micro hardness and tensile stress exhibited an increase by ECAP; Breakdown potential in Tafel increased with the increasing number of ECAP passes. The increasing of corrosion potential can be explained by a shift in the boundary between imperfect passivity and the corrosion region. It indicated that the protective passive layer in the ECAPed sample is more stable than the as-received sample.

In this paper, steel Q235 is employed to perform the study. Q235 steel is a common used steel due to its advantages of low cost, process ability, relatively high strength and stiffness, it is widely used in building and engineering construction, frameworks, towers of high - voltage transmission, bridges, vehicles, boilers, containers, ships, etc., as well as mechanical parts in cases of no serious performance requirements [7-11]. A new application of Q235 steel pipe is as the base pipe of bimetallic composite pipe by using double metal extrusion method to produce such a composite pipe for pipeline application. In the process of bimetallic composite pipe production, the base pipe, such as Q235 steel carbon pipe, often bears some elastic or even plastic deformation, besides the plastic deformation of the liner layer. Therefore, the study the influence of deformation on electrochemical properties of Q235 steel is important in some sense. In this paper, the uniaxial tension of Q235 steel is conducted on universal testing machine to different degrees. Afterward, the tests of potentiodynamic polarization and electrochemical impedance spectroscopy are conducted to reveal the influence of deformation on electrochemical property for Q235 steel in 0.01 mol.dm ${ }^{-3} \mathrm{NaCl}$ solution.

\section{TEST MATERIALS AND METHODS}

The experimental material is Q235-A3 carbon steel, its chemical composition is shown in Table 1; the tensile specimen was prepared according to Chinese GB GBT228-2002, the total length of Dumbbell shaped cylinder specimen is $210 \mathrm{~mm}$ with the diameter of $10 \mathrm{~mm}$, and the length in the parallel part is $120 \mathrm{~mm}$. The specimens are divided into four groups, namely, the original specimen, and deformed specimens with the strains of $0.07 \%, 6 \%, 11 \%$ and $24 \%$, respectively. In order to ensure the accuracy of test results, each level contains three specimens, and all the samples are numbered from 1 to 15 ; after tensile test, the specimen is then machined to be a cylinder with the height of $10 \mathrm{~mm}$ as the working electrode, its one plane surface is polished and will be immersed into the corrosion solution, the other plane surface is solder with $\mathrm{Cu}$ wire, and the lateral surface is sealed with epoxy resin in the PVC pipe. The polishing is conducted with $\mathrm{SiC}$ water sandpaper progressively till 2000 \#, after polishing the sample is washed with ethanol and deionized water. The corrosion solution is $0.01 \mathrm{~mol}$. $\mathrm{dm}^{-3} \mathrm{NaCl}$ solution, and the solution is configured by using analytical chemical agent and deionized water. The test is conducted at room temperature $\left(24^{\circ} \mathrm{C} \pm 1\right)$.

The tensile test is conducted on the SANS electrohydraulic servo universal testing machine, the electrochemical test is completed on the PARSTAT2273 electrochemical workstation by using the three-electrode system, the auxiliary electrode selection is Pt electrode, the reference electrode is the saturated calomel electrode (SCE). Before test, the working electrode is polarized at $-1.1 \mathrm{~V}$ (vs. SCE) for $30 \mathrm{~min}$ to remove the oxide film on the surface of the sample; the range of the dynamic polarization was $-0.5 \mathrm{~V} \sim 0.9 \mathrm{~V}$ (vs. SCE), the scanning rate was $2 \mathrm{mV} / \mathrm{s}$, EIS spectrum test frequency ranges $10 \mathrm{mHz} \sim 100 \mathrm{kHz}$, the measured signal was the sine wave with the amplitude of $10 \mathrm{mV}$.

Tab. 1. Chemical composition of Q235-A steel (wt $\%$ ) / Chemické složeni oceli Q235-A (hm.\%)

\begin{tabular}{|c|c|c|c|c|c|c|}
\hline Element & $\mathbf{C}$ & Mn & Si & S & P & Fe \\
\hline Content & $\leq 0.22$ & $\leq 1.4$ & $\leq 0.35$ & $\leq 0.050$ & $\leq 0.045$ & remaining \\
\hline
\end{tabular}

\section{EXPERIMENTAL RESULTS AND ANALYSIS}

\section{Potentiodynamic polarization}

Figure 1 shows the polarization curves of the deformed Q235 steel in $0.01 \mathrm{~mol} \mathrm{dm}^{-3} \mathrm{NaCl}$ solution. Figure 2 and Table 2 show the fitting results of Tafel polarization curve, in which the curves 1,2 and 3 indicate the original samples, curves 4,5 and 6 indicate the deformed samples of the strain about $0.07 \%$, i.e. within elastic range; curves 7,8 and 9 indicate the deformed samples of the strain $6 \%$; curves 10,11 , and 12 indicate the deformed samples of the strain about $11 \%$; the curves 13,14 and 15 indicate the deformed samples of the strain about $24 \%$. 


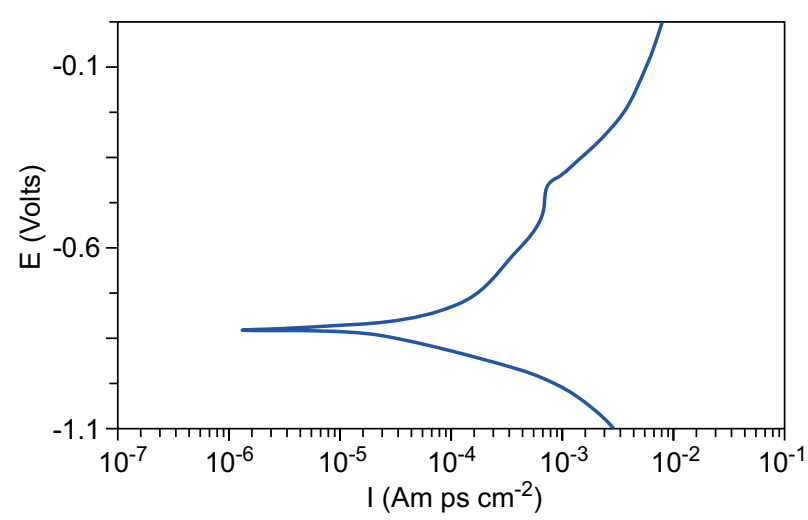

Fig 1. Polarization curve of deformed Q235 steel in 0.01 mol. $\mathrm{dm}^{-3} \mathrm{NaCl}$ solution

Obr. 1. Polarizační křivka deformované oceli Q235 v roztoku $0.01 \mathrm{~mol} . \mathrm{dm}^{-3} \mathrm{NaCl}$

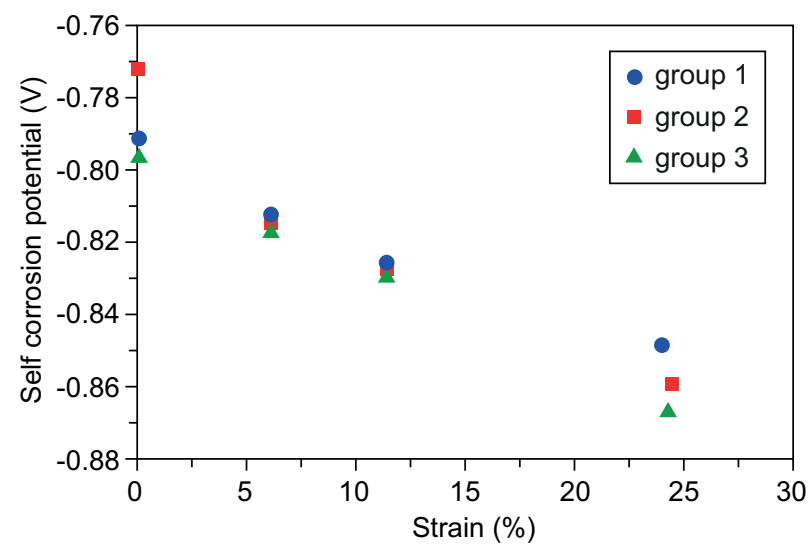

Fig. 2. Variation of self corrosion potential of Q235 steel with respect to deformation

Obr. 2. Rozptyl hodnot korozního potenciálu oceli Q235 vzhledem $k$ deformaci

The results in Figure 2 and Table 2 show that the deformation in elastic range, i.e. $0.07 \%$, almost doesn't induce visible change of corrosion performance of Q235 steel; the corrosion potential moves to negative significantly and the corresponding corrosion current density becomes larger with the increase of deformation for Q235 steel. Above results indicate that the corrosion resistance of Q235 steel decreases with the deformation. According to Faraday's formula, the uniform electrochemical corrosion rate can be determined by measuring the corrosion current density [8],

$$
V=\frac{\mathrm{M} \cdot \mathrm{I}_{\text {corr }}}{N \cdot \mathrm{F}}
$$

in which, $V$ is the corrosion mass loss per unit time of the metal material per unit area; $I_{\text {corr }}$ is corrosion current density, $M$ is the atomic mass of the corrosion metal; $n$ is the valence of the metal ion; $F$ is the Faraday's constant. Thus, according to Eq. (1), the test data in Table 1 shows that the corrosion rate of Q235 steel increases with the deformation.
Tab. 2. Fitted results of polarization curves of Q235 steel / Tafelovy analýzy potenciodynamických křivek oceli Q235

\begin{tabular}{|c|c|c|c|}
\hline Specimen & Strain $\boldsymbol{\varepsilon} \mathbf{( \% )}$ & $\mathbf{E}_{\text {corr }} \mathbf{( V )}$ & $\mathbf{I}_{\text {corr }}\left(\mathbf{A} / \mathbf{c m}^{2}\right)$ \\
\hline 1 & 0 & -0.79147 & $-1.8532 \cdot 10^{-5}$ \\
\hline 2 & 0 & -0.79663 & $-1.9772 \cdot 10^{-5}$ \\
\hline 3 & 0 & -0.77282 & $-1.5792 \cdot 10^{-5}$ \\
\hline 4 & 0.1 & -0.76468 & $-1.2580 \cdot 10^{-5}$ \\
\hline 5 & 0.1 & -0.77105 & $-1.5656 \cdot 10^{-5}$ \\
\hline 6 & 0.1 & -0.76926 & $-1.2594 \cdot 10^{-5}$ \\
\hline 7 & 6 & -0.81380 & $-2.2468 \cdot 10^{-5}$ \\
\hline 8 & 6 & -0.81286 & $-2.3293 \cdot 10^{-5}$ \\
\hline 9 & 6 & -0.81663 & $-2.4944 \cdot 10^{-5}$ \\
\hline 10 & 11 & -0.82713 & $-2.9519 \cdot 10^{-5}$ \\
\hline 11 & 11 & -0.82785 & $-2.7654 \cdot 10^{-5}$ \\
\hline 12 & 11 & -0.82898 & $-2.8083 \cdot 10^{-5}$ \\
\hline 13 & 24 & -0.86558 & $-6.3578 \cdot 10^{-5}$ \\
\hline 14 & 24 & -0.85841 & $-4.2905 \cdot 10^{-5}$ \\
\hline 15 & 24 & -0.84826 & $-3.2050 \cdot 10^{-5}$ \\
\hline
\end{tabular}

\section{Electrochemical impedance}

Figure 3 shows the Nyquist curve of Q235 steel samples in 0.01 mol.dm ${ }^{-3} \mathrm{NaCl}$ solution after different deformation. As can be seen from Figure 3 that each Nyquist curve consists of a single circular arc, which indicates that the electrochemical reaction is the only controlling factor of the corrosion; it can be found in Fig. 3 that the radius of the arc becomes smaller with increase of the deformation amount gradually. In general, the size of arc in the Nyquist plot is the indictor of the corrosion resistance of material, the greater the radius of curvature, the better its corrosion resistance [9-11], therefore, deformation leads to a visible reduction of

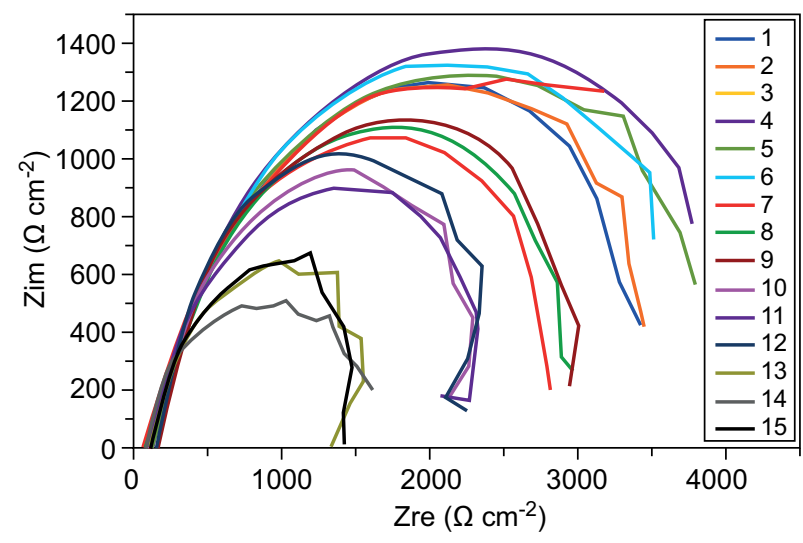

Fig. 3. Nyquist curves of deformed Q235 steel samples in $0.01 \mathrm{~mol}^{\mathrm{d} \mathrm{dm}^{-3} \mathrm{NaCl} \text { solution }}$

Obr. 3. Nyquistovy diagramy deformované oceli Q235 v roztoku $0.01 \mathrm{~mol} . \mathrm{dm}^{-3} \mathrm{NaCl}$ 
corrosion resistance of Q235 steel. The main resource of deformation inducing decrease of corrosion resistance is due to the increase of internal dislocation defects, which also results in work- hardening of metal [12].

According to the characteristics of impedance spectroscopy, Figure 4 shows the equivalent circuit diagram of Q235 steel, in which $R s$ represents the solution resistance, $R t$ represents the charge transfer resistance, and $C P E$ indicates the electric double layer capacitor. Based on dispersion effect, in the equivalent circuit, the pure capacitive element could be replaced by constant phase element $C P E$ [13], the $C P E$ impedance can be written as,

$$
Z^{\prime}=\frac{1}{\left(Y_{0} i \omega\right)^{n}}
$$

Therefore, the total impedance of the equivalent circuit can be expressed as

$$
Z=R_{s}+\frac{1}{1 / R_{t}+1 / Z^{\prime}}=R_{s}+\frac{1}{1 / R_{t}+\left(Y_{0} i \omega\right)^{n}}
$$

in which, $Y_{0}$ and $n$ are two parameters of the $C P E$, the dimension of $Y_{0}$ is the same as that of capacitance, $n$ is dimensionless, called diffusion index, ranging in the interval of $(0,1)$.

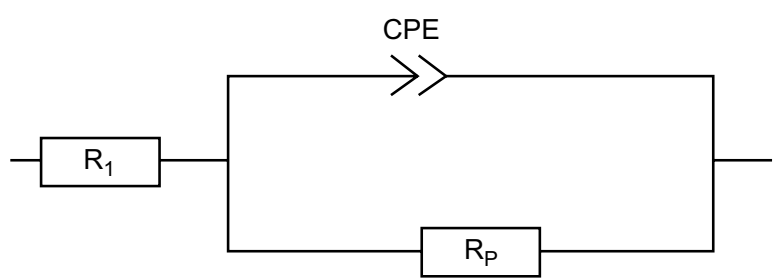

Fig. 4. Equivalent circuit diagram of Q235 steel corrosive sample

Obr. 4. Ekvivalentní obvod pro fitování impedančních spekter

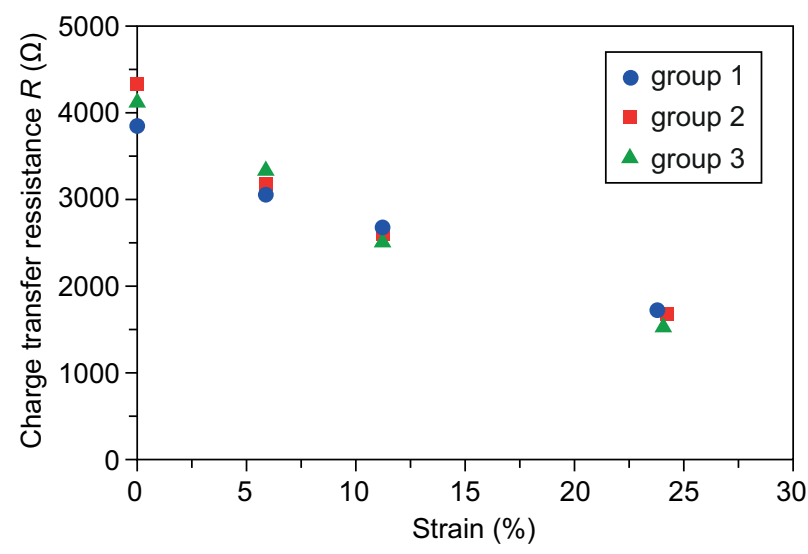

Fig. 5. Variation of charge transfer resistance with respect to

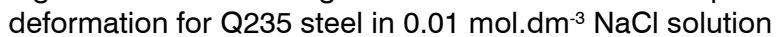
Obr. 5. Rozptyl hodnot odporu proti přenosu náboje na oceli Q235 v roztoku $0.01 \mathrm{~mol}^{-\mathrm{dm}^{-3} \mathrm{NaCl}}$
Figure 5 and Table 3 show the fitting results for each parameter from the equivalent circuit diagram in Fig. 3 by using ZSimp Win software. It can be seen the that the diffusion index $n$ remains at around 0.75 almost; the charge transfer resistance of Q235 steel isn't obvious within the elastic deformation range, while the charge transfer resistance of the material decreases seriously with the increase of the amount of strain in plastic deformation range.

Tab. 3. Fitting results of nyquist curve / Výsledky fitování impedančních spekter

\begin{tabular}{|c|c|c|c|c|c|}
\hline $\begin{array}{c}\text { Specimen } \\
\text { No. }\end{array}$ & $\begin{array}{c}\text { Strain } \\
(\mathbf{\%})\end{array}$ & $\begin{array}{c}\mathbf{R}_{\mathbf{s}} \\
\left(\mathbf{\Omega} \mathbf{c m}^{-2}\right)\end{array}$ & $\begin{array}{c}\mathbf{Y}_{\mathbf{0}} \\
\left(\mathbf{F} \mathbf{c m}^{-2}\right)\end{array}$ & $\mathbf{n}$ & $\begin{array}{c}\mathbf{R}_{\mathbf{t}} \\
\left(\mathbf{\mathbf { ~ m } ^ { - 2 }}\right)\end{array}$ \\
\hline 1 & 0 & 108.4 & $4.615 \cdot 10^{-4}$ & 0.7275 & 3893 \\
\hline 2 & 0 & 109.2 & $4.467 \cdot 10^{-4}$ & 0.7392 & 3819 \\
\hline 3 & 0 & 109.0 & $4.755 \cdot 10^{-4}$ & 0.7345 & 4109 \\
\hline 4 & 0.1 & 109.1 & $4.667 \cdot 10^{-4}$ & 0.7326 & 4330 \\
\hline 5 & 0.1 & 146.8 & $6.172 \cdot 10^{-4}$ & 0.7274 & 4175 \\
\hline 6 & 0.1 & 87.2 & $9.044 \cdot 10^{-4}$ & 0.7018 & 4287 \\
\hline 7 & 6 & 105.2 & $5.177 \cdot 10^{-4}$ & 0.7647 & 3050 \\
\hline 8 & 6 & 105.0 & $5.354 \cdot 10^{-4}$ & 0.7590 & 3212 \\
\hline 9 & 6 & 104.6 & $5.463 \cdot 10^{-4}$ & 0.7575 & 3283 \\
\hline 10 & 11 & 102.6 & $4.871 \cdot 10^{-4}$ & 0.7978 & 2573 \\
\hline 11 & 11 & 87.2 & $4.769 \cdot 10^{-4}$ & 0.7651 & 2492 \\
\hline 12 & 11 & 88.8 & $4.534 \cdot 10^{-4}$ & 0.7393 & 2666 \\
\hline 13 & 24 & 97.3 & $8.385 \cdot 10^{-4}$ & 0.7648 & 1664 \\
\hline 14 & 24 & 67.5 & $8.118 \cdot 10^{-4}$ & 0.7170 & 1614 \\
\hline 15 & 24 & 97.4 & $9.795 \cdot 10^{-4}$ & 0.7678 & 1681 \\
\hline
\end{tabular}

\section{Microstructure of deformed Q235 steel and its influence on electrochemical property}

The microstructures of the deformed Q235 steel are tested with the conventional method, which are shown in Figures 6 and 7 .

It can be seen from Figures 6 and 7, that the crystalline grains refine in the view of transverse section area with the progress of deformation, and elongate in the view of longitudinal section area in tensile direction with the progress of deformation. The fraction of crystalline boundary increases with the progress of deformation, it induces more corrosive possibility, and lower corrosive resistance. This tendency accords with the experimental results of corrosive tests for Q235 steel reported in the last paragraph.

As to the long-term impedance experiments for corrosion behavior description in time, Sürme \& Gürten studied the corrosion behavior of mild steel in $1 \mathrm{~mol}^{\mathrm{d}} \mathrm{dm}^{-3}$ $\mathrm{HCl}$ solution at $298 \mathrm{~K}$ in the presence and absence of inhibitor Triton X-114 with electrochemical impedance and polarisation tests [14]. They found that under inhibitor 
free condition the solution resistance $R_{S}$ remains stably with immersion time till $168 \mathrm{~h}$, while the polarisation resistance $R_{P}$ increases with time; comparatively, in the presence of inhibitor Triton $\mathrm{X}-114$ the radius of capacitive loop increases significantly after $24 \mathrm{~h}$. They attributed it to the oxygen atom and aromatic ring of the molecular structure of inhibitor molecule; it obtained the inhibition efficiency of $97 \%$ for the immersion time 24 $\mathrm{h}$, which indicates the relatively higher adsorption rate of the inhibitor Triton X-114 on the mild steel surface.

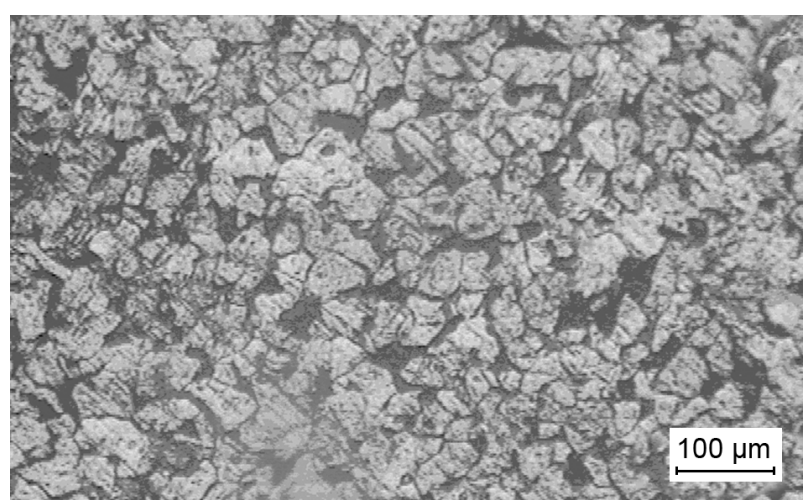

a)

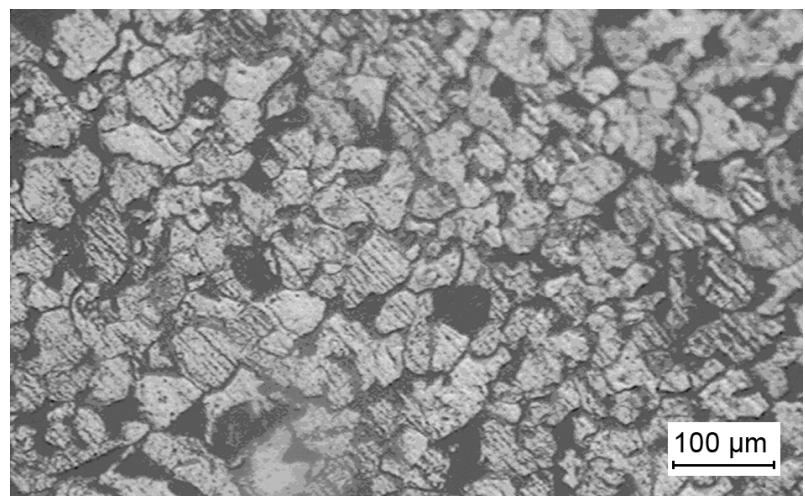

b)

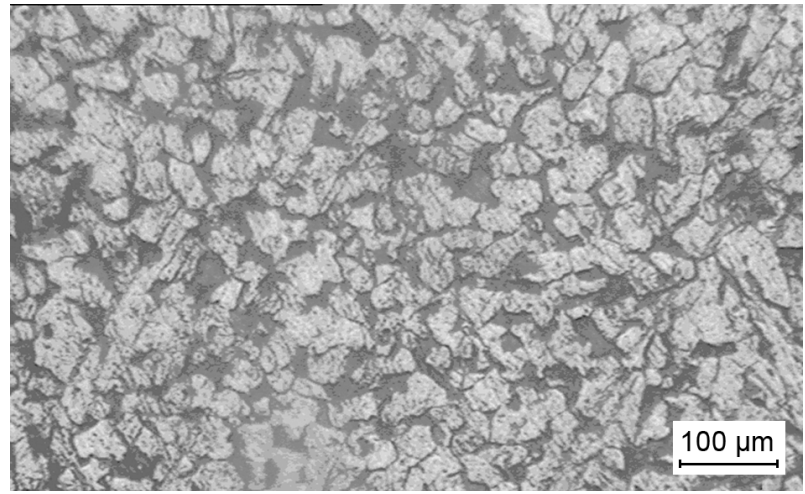

c)

\section{CONCLUSIONS}

From above analysis, it can be concluded:

- Plastic deformation leads to crystalline grains refine and elongate, and crystalline boundary increases, it induces more corrosive possibility and lower corrosive resistance;

- The corrosion potential of Q235 steel moves to more negative with the increase of tensile deformation, and its corrosion current density increases with the amount of deformation seriously, which indicates the reduction of corrosion resistance of Q235 steel with tensile deformation.

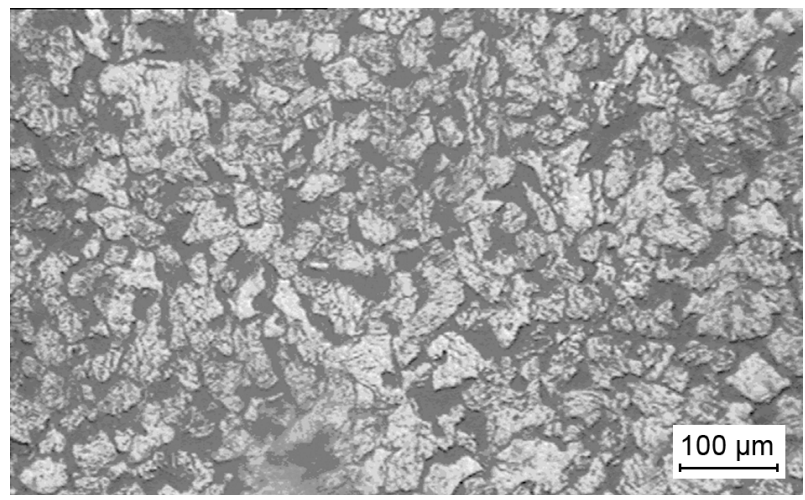

d)

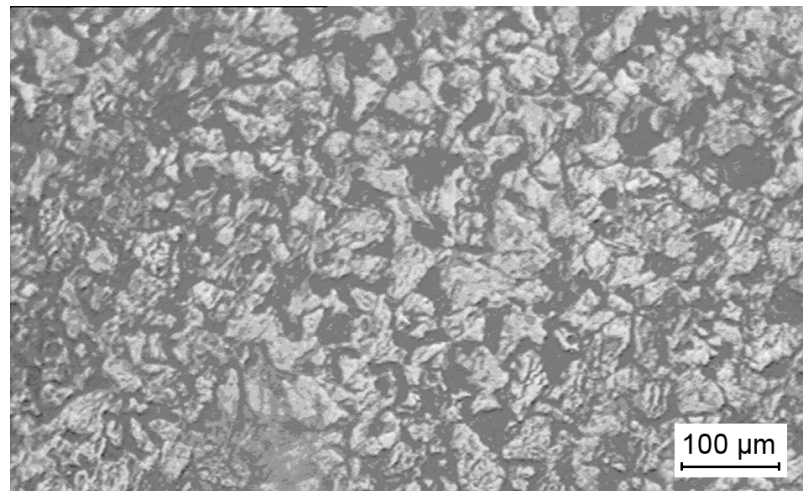

e)

Fig. 6. Microstructures of the deformed Q235 steel in transverse section area: a) undeformed; b) deformed in elastic range; c) deformation $6 \%$; d) deformation $11 \%$; e) deformation $24 \%$

Obr. 6. Mikrostruktura deformované oceli Q235 kolmo na směr deformace: a) nedeformovaný; b) deformovaný v elastické oblasti; c) deformace 6\%; d) deformace 11\%; e) deformace $24 \%$ 


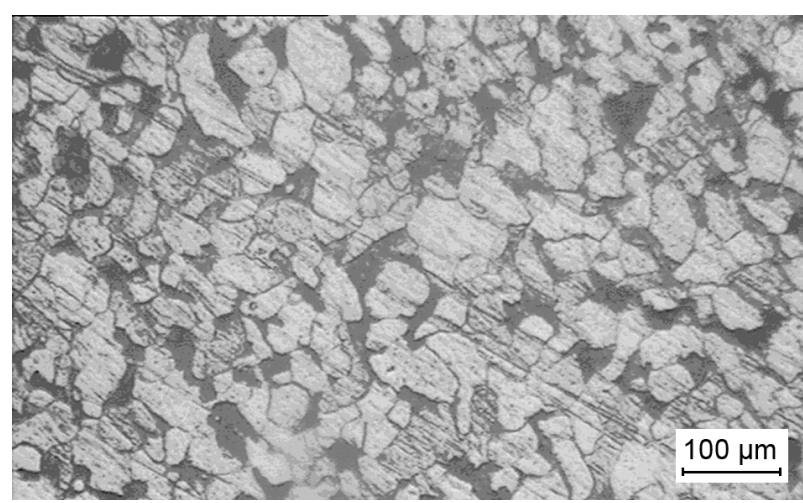

a)

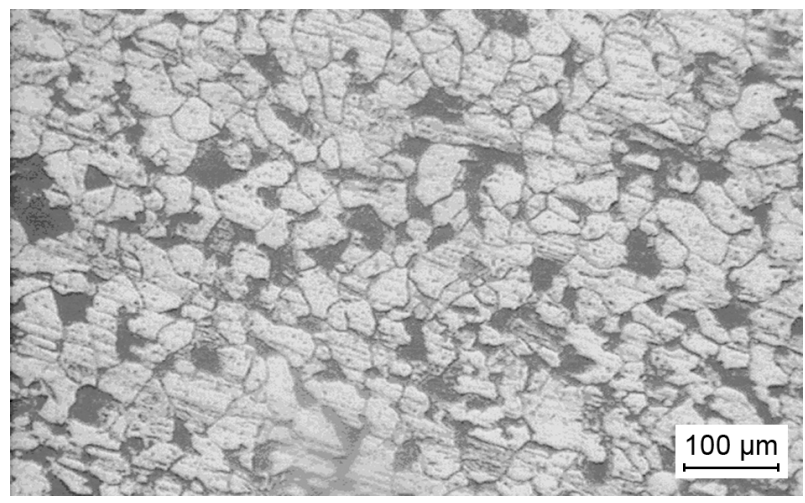

b)

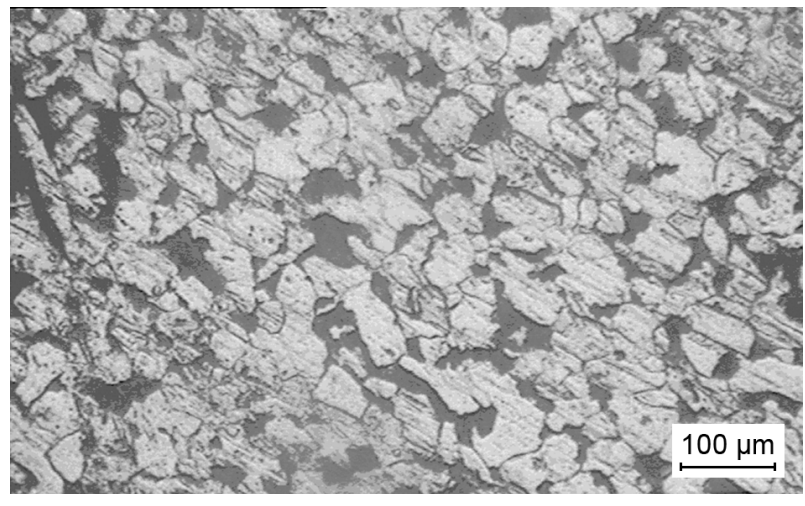

c)

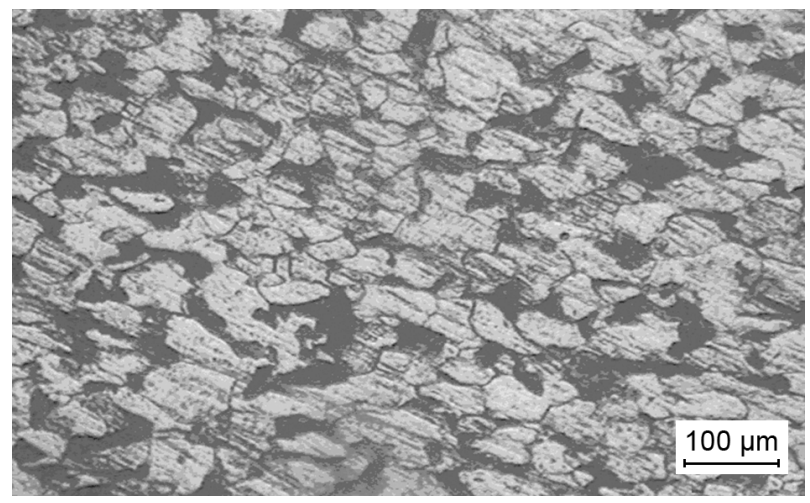

d)

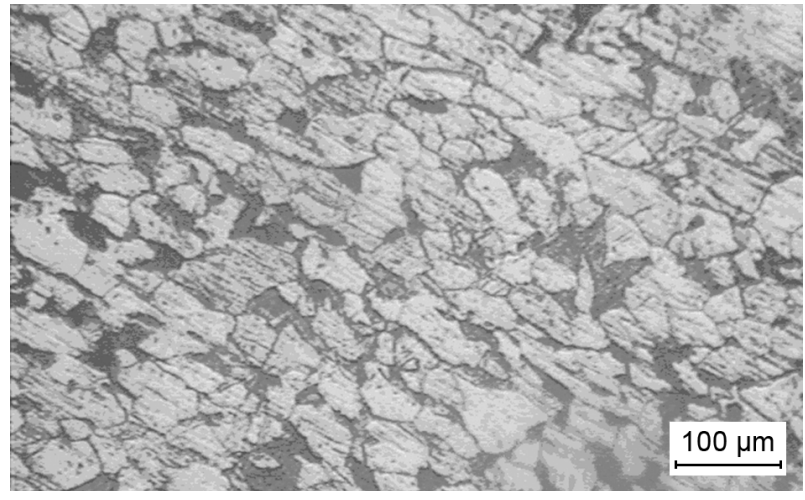

e)

Fig. 7. Microstructures of the deformed Q235 steel in longitudinal section area: a) undeformed; b) deformed in elastic range; c) deformation $6 \%$; d) deformation $11 \%$; e) deformation $24 \%$

Obr. 7. Mikrostruktura deformované oceli Q235 podélně ve směru deformace: a) nedeformovaný; b) deformovaný v elastické oblasti; c) deformace 6\%; d) deformace $11 \%$; e) deformace $24 \%$

\section{REFERENCES}

1. M. K. Singh, A. Kumar, Environmental corrosion studies of cold rolled Austenitic stainless steel, Inter. J. of Adv. Eng. Tech. 2012, 3 (1), 75-79.

2. P. Jacques, F. Lefebvre, C. Lemaignan, Deformation corrosion interactions for $\mathrm{Zr}$ alloys during, I-SCC crack initiation Part I: Chemical contributions, J. of Nuclear Mater. 1999, 264, 239-248.

3. P. Jacques, F. Lefebvre, C. Lemaignan, Deformation corrosion interactions for $\mathrm{Zr}$ alloys during I-SCC crack initiation: Part II: Localised stress and strain contributions, J. of Nuclear Mater. 1999, 264, 249-256.

4. V. A. C. Haanappel, M. F. Stroosnijder, Influence of mechanical deformation on the corrosion behavior of AISI 304 stainless steel obtained from cooking utensils, Corrosion 2001, 57 (6), 557-565.

5. B. Mazza, P. Pedeferri, D. Sinigaglia, A. Cigada, L. Lazzari, G. Re, D. Wenged, Relationship between the electrochemical and corrosion behavior and the structure of stainless steels subjected to cold plastic deformation, Electrochem. Soc.: Electrochemical Science \& Technology 1976, 123, 1157-1163. 
6. M. Rifai, H. Miyamoto, H. Fujiwara, The effect of ECAP deformation route on microstructure, mechanical and electrochemical properties of low $\mathrm{CN} \mathrm{Fe}-20 \% \mathrm{Cr}$ alloy, Materials Sciences and Applications 2014, 5, 568-578.

7. M. Zhu, C. Du, X. Li, Z. Liu, W. Yao, L. Huang, Corrosion behavior of Q235 steel in Beijing soil environment, $J$. of Chinese Society for Corrosion and Protection 2013, 33 (3), 199-204.

8. J. Xiao and C. Cao, Principle of material corrosion, Beijing, Chemical Industry Press, 2002.

9. F. M. Queiroz, I. Costa, Electrochemical, chemical and morphological characterization of galvannealed steel coating, Surface and Coatings Technology 2007, 201, 7024-7035.

10. S.T. Vagge, V.S. Raja, R. Ganesh Narayanan, Effect of deformation on the electrochemical behavior of hot-dip galvanized steel sheets, Applied Surface Science 2007, 253, 8415-8421. 0
11. V.S. Raja, C.K. Panday, V.S. Saji, S.T. Vagge, K. Narasimhan, An electrochemical study on deformed galvanneal steel sheets, Surface and Coatings Technology 2006, 201, 2296-2302.

12. D. Guo, X. Yuan, B. Gu, et al, Influence of deformation of galvanized alloyed steel on corrosion resistance, Materials and Heat Treatment 2013, 34 (8), 153-157.

13. Q. Xue, M. Zheng, L. Han, Effect of passive film potential on electrochemical properties of oil casing P110 steel, Corrosion Science and Protection Technology 2013, 25 (2), 152-155.

14. Y. Sürme \& A. Ali Gürten, Role of polyethylene glycol tertoctylphenyl ether on corrosion behaviour of mild steel in acidic solution, Corrosion Engineering, Science and Technology 2009, 44 (4), 304-311. 